\title{
DISSOLUTION OF PSEUDOPHAKIC FIBRINOUS EXUDATE WITH INTRAOCULAR STREPTOKINASE
}

\author{
PAUL B. MULLANEY, DAVID T. WHEELER and TALAL AL-NAHDI \\ Riyadh, Saudi Arabia
}

\begin{abstract}
SUMMARY
A fibrinous exudate developed in 8 children after cataract extraction. Blunt trauma was the cause of cataract formation in 6 children; the other 2 presented with congenital cataract. In 4 of 6 children with traumatic cataract, iris damage was evident. Seven children had an intraocular lens implanted. The development of fibrinous exudate in the anterior chamber was noted despite routine post-operative topically administered steroids. It typically formed 1-4 days after surgery. In all cases topical fortified steroids were unsuccessful in hastening dissolution. Intracameral injection of streptokinase (500-1000 IU) caused dissolution of fibrin in all cases. No adverse effects were apparent clinically with intraocular administration of streptokinase.
\end{abstract}

Lensectomy with intraocular lens (IOL) implantation is currently an accepted mode of aphakic correction in children who may be poorly compliant with contact lenses. ${ }^{1-3}$ Severe inflammatory reactions may occur in children after lensectomy with IOL implantation. ${ }^{4,5}$ Usually this can be suppressed with intensive topical fortified prednisolone. In a minority of patients the formation of a fibrinous exudate occurs which may be difficult to eradicate. When fibrin occludes the visual axis, difficulties with refraction, fundus examination and consequently amblyopia therapy ensue.

Streptokinase has been used as a fibrinolytic agent in coronary artery, arterial and deep venous thrombosis. We report 8 patients who developed intractable fibrinous exudate following cataract surgery in whom streptokinase caused complete dissolution of the fibrin.

\section{PATIENTS AND METHODS}

Between January 1993 and June 1995, 8 children received intracameral streptokinase injections to

Correspondence to: Dr Paul B. Mullaney, c/o Medical Library, King Khaled Eye Specialist Hospital, PO Box 7191, Riyadh 11462, Saudi Arabia. Fax: 966-1-482-1908. dissolve topical-steroid-resistant fibrin exudates. Six children developed cataracts following blunt trauma (Table I). Of these, 4 had iris trauma manifested by posterior synechiae and sphincter ruptures. One patient (case 3) had an inferior zonular dialysis with prolapse of the anterior hyaloid into the anterior chamber. Two children presented with congenital cataracts. An IOL was implanted in all except one patient (case 5), in whom the extent of iris and anterior capsule damage was deemed too great for safe IOL implantation. Anterior vitrectomy was performed in case 3 to remove vitreous anterior to the IOL and in case 4 following posterior capsulotomy to ensure a clear visual axis. There were no surgical complications apart from fibrin exudation in case 7. Pre-operative topical steroids were not used and post-operative subconjunctival decadron $(1 \mathrm{mg})$ was injected in all cases.

The formation of fibrin occurred from 1 to 4 days after surgery, and despite the use of routine topical steroids. Topical hourly fortified prednisolone was administered in an attempt to lyse the fibrin. When this failed, intracameral streptokinase was injected. First 1000 international units (IU) of purified lyophilised streptokinase (Kabikinase, Kabivitrum, Stockholm, Sweden) was diluted in $0.1 \mathrm{ml}$ of balanced salt solution, and then between 500 and $1000 \mathrm{IU}$ of streptokinase was injected into the anterior chamber using a microlitre syringe and a 30 -gauge needle. In cases 2 and 5 the procedure was performed with topical anaesthesia. In case 7 , a marked fibrinous response was noted during lensectomy which covered the iris in web-like strands; perioperative streptokinase $750 \mathrm{IU}$ was used to lyse these strands. The remaining patients required mask anaesthesia. After the injection, topical antibiotics were instilled and the eyes were patched.

Photographs of the patients were obtained before and after injection. In all patients except case 1 , complete dissolution of fibrin was noted within 24 hours of injection. In case 1, intracameral streptoki-

Eye (1996) 10, 362-366 c) 1996 Royal College of Ophthalmologists 
Table I. Dissolution of fibrinous exudate in eight paediatric patients after cataract extractions

\begin{tabular}{|c|c|c|c|c|c|c|c|c|c|c|}
\hline $\begin{array}{l}\text { Case } \\
\text { no. }\end{array}$ & Sex & Age & $\begin{array}{l}\text { Cause of } \\
\text { cataract }\end{array}$ & $\begin{array}{l}\text { Other pre-opera- } \\
\text { tive findings }\end{array}$ & $\begin{array}{l}\text { - Surgery } \\
\text { performed }\end{array}$ & $\begin{array}{l}\text { Surgical } \\
\text { complica- } \\
\text { tions }\end{array}$ & $\begin{array}{l}\text { Fibrin form. } \\
\text { time (post-op. } \\
\text { days) }\end{array}$ & $\begin{array}{c}\text { Time and } \\
\text { amount of } \\
\text { streptokinase } \\
\text { injection }\end{array}$ & $\begin{array}{l}\text { Time of } \\
\text { fibrin dis- } \\
\text { solution } \\
\text { (days) }\end{array}$ & $\begin{array}{l}\text { Compli- } \\
\text { cations of } \\
\text { injection }\end{array}$ \\
\hline 1 & $\mathrm{~F}$ & 9 years & $\begin{array}{l}\text { Blunt } \\
\text { trauma }\end{array}$ & $\begin{array}{l}\text { Posterior } \\
\text { synechiae }\end{array}$ & $\begin{array}{l}\text { Synechialysis, } \\
\text { ECCE, IOL, } \\
\text { nucleus delivered }\end{array}$ & None & 2 & 6 days/500 IU & 2 & None \\
\hline 2 & M & 13 years & $\begin{array}{l}\text { Blunt } \\
\text { trauma }\end{array}$ & $\begin{array}{l}\text { Iris sphincter } \\
\text { rupture; trau- } \\
\text { matic mydriasis } \\
\text { cortex in AC }\end{array}$ & $\begin{array}{l}\text { Lensectomy, IOL } \\
\text { implantation }\end{array}$ & None & 1 & 3 days $/ 1000$ IU & 1 & None \\
\hline 3 & $\mathrm{~F}$ & 10 years & $\begin{array}{l}\text { Blunt } \\
\text { trauma }\end{array}$ & $\begin{array}{l}\text { Herniation of } \\
\text { anterior hyaloid } \\
\text { into AC }\end{array}$ & $\begin{array}{l}\text { Lensectomy, } \\
\text { anterior } \\
\text { vitrectomy, IOL } \\
\text { implantation }\end{array}$ & None & 1 & 6 days/1000 IU & 1 & None \\
\hline 4 & M & $\begin{array}{l}2 \text { years } \\
8 \text { months }\end{array}$ & Congenital & None & $\begin{array}{l}\text { Lensectomy, pos- } \\
\text { terior capsulot- } \\
\text { omy, anterior } \\
\text { vitrectomy, IOL } \\
\text { implantation }\end{array}$ & None & 3 & 6 days $/ 1000 \mathrm{IU}$ & 1 & None \\
\hline 5 & M & 11 years & $\begin{array}{l}\text { Blunt } \\
\text { trauma }\end{array}$ & $\begin{array}{l}\text { Cortex in AC, } \\
\text { elevated IOP, } \\
\text { sphincter }\end{array}$ & Lens aspiration & None & 1 & 2 days/1000 IU & 1 & None \\
\hline 6 & $\mathrm{~F}$ & $\begin{array}{l}2 \text { years } \\
3 \text { months }\end{array}$ & Congenital & None & $\begin{array}{l}\text { Lensectomy, IOL } \\
\text { implantation }\end{array}$ & None & 4 & 7 days/500 IU & 1 & None \\
\hline 7 & M & $\begin{array}{l}5 \text { years } \\
6 \text { months }\end{array}$ & $\begin{array}{l}\text { Blunt } \\
\text { trauma }\end{array}$ & $\begin{array}{l}\text { Hyphaema, } \\
\text { posterior } \\
\text { synechiae }\end{array}$ & $\begin{array}{l}\text { Lensectomy, pos- } \\
\text { terior capsule } \\
\text { discission, IOL } \\
\text { implantation }\end{array}$ & $\begin{array}{l}\text { Massive } \\
\text { fibrin } \\
\text { exudation }\end{array}$ & 0 & $\begin{array}{l}\text { Peri-operative } \\
750 \text { IU }\end{array}$ & 1 & None \\
\hline 8 & $\mathrm{M}$ & 10 years & $\begin{array}{l}\text { Blunt } \\
\text { trauma }\end{array}$ & None & $\begin{array}{l}\text { Lensectomy, IOL } \\
\text { implantation }\end{array}$ & None & 2 & 4 days/500 IU & 1 & None \\
\hline
\end{tabular}

AC, anterior chamber; ECCE, extracapsular cataract extraction; IOL, intraocular lens่.

nase markedly reduced intraocular fibrin but did not eradicate it; however, on the first post-operative clinic visit all fibrin had been lysed. This dissolution of fibrin was usually associated with a moderate increase in proteinaceous and cellular material in the anterior chamber. Intensive fortified steroids were continued after streptokinase injection to enhance resolution of this material. The intraocular pressure remained below $20 \mathrm{mmHg}$ in all cases. No changes in corneal clarity were noted in any patient after injection. Specular microscopy was not performed. Though the greatest effect of injection was noted within the first 24 hours, further gradual clearing of the anterior surface of the IOL was noted in the ensuing weeks.

\section{SELECTED CASE REPORTS}

Case 2

A 13-year-old boy presented with a left traumatic cataract following blunt non-penetrating ocular trauma. Cortical material was present in the anterior chamber and the intraocular pressure in this eye was $33 \mathrm{mmHg}$. Traumatic mydriasis was present as a result of multiple iris sphincter ruptures. The right eye presented an anterior subcapsular lens opacity at exactly the site of anterior capsular rupture in the left eye. The following day an uneventful lensectomy was performed and an AMO PC $25 \mathrm{~TB},+17.50 \mathrm{IOL}$ implanted in the capsular bag. Twenty-four hours post-operatively a fibrin plaque was adherent to the IOL and completely filled the visual axis (Fig. 1). The administration of hourly fortified prednisolone drops was started and continued for 48 hours with no resolution of the plaque. Under topical anaesthesia, streptokinase 1000 IU was injected intracamerally, leading to complete dissolution of the plaque within 24 hours. Apart from a heavy flare, no complications were noted. Some small clumps of pigment cells were left adherent to the IOL (Fig. 2), but these subsequently cleared. When last reviewed, 15 months after surgery, the anterior surface of the IOL was completely clear and visual acuity in this eye was 20/30 uncorrected (Fig. 3).

\section{Case 3}

A 10-year-old girl presented with a right cataractous lens after recent blunt trauma. An inferior zonular dehiscence was associated with herniation of the intact anterior hyaloid face into the anterior chamber. Nineteen days later, the child underwent uncomplicated lensectomy with IOL implantation in the bag. This was followed by removal of vitreous in the anterior chamber with the ocutome. A large fibrinous veil was present on the first post-operative day (Fig. 4). Hourly fortified prednisolone drops were administered. Five days later no change in the fibrinous veil was seen and intracameral streptokinase 600 IU was injected under mask anaesthesia. Six 


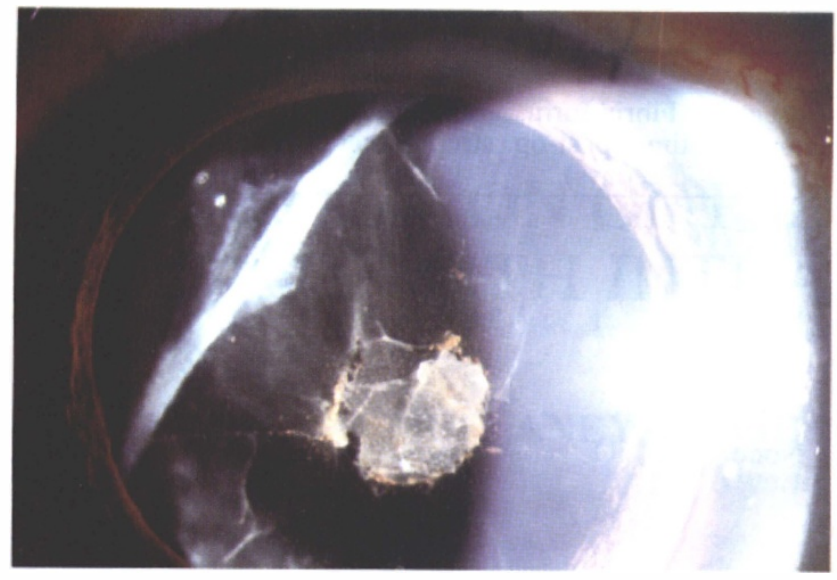

Fig. 1. Case 2. Discrete central fibrin plaque which is densely adherent to the IOL.

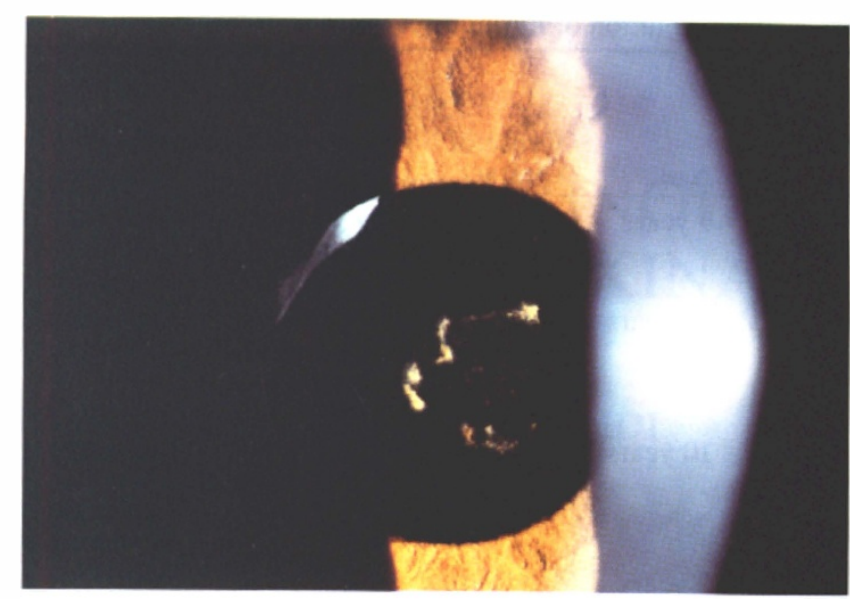

Fig. 2. Case 2. Small clumps of pigment are still attached to the IOL 24 hours after streptokinase administration.

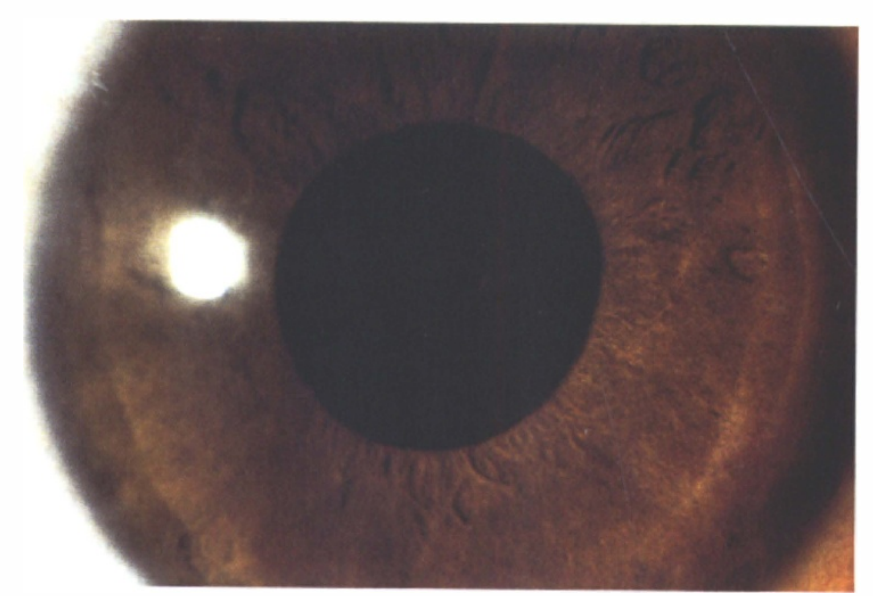

Fig. 3. Case 2. Six months later, the anterior surface of the IOL is completely clear.

hours later, slit lamp examination revealed complete dissolution of all fibrin (Fig. 5). A marked cellular and proteinaceous reaction was present. This resolved with the use of intensive topical fortified steroids. Two months after surgery the child maintained a clear anterior IOL surface. Her intraocular pressure was $21 \mathrm{mmHg}$ and her cornea was clear.

\section{Case 4}

A left monocular congenital cataract was a presenting feature in a 32-month-old boy. His fixation was uncentral, unsteady and unmaintained in this eye. As his parents felt that the child would not be compliant with contact lens use an elective IOL implantation was decided upon. Once placement of the IOL occurred within the capsular bag, a posterior capsulotomy and limited anterior vitrectomy followed. No perioperative iris trauma occurred. The first post-operative examination revealed no inflammatory reaction. Forty-eight hours after the surgery, significant anterior chamber cells and flare were seen. Intensive hourly steroids were commenced.
However, examination on the third post-operative day revealed a dense fibrin plaque on the IOL (Fig. 6 ). A further 3 days of intensive fortified steroid administration failed to reduce the size of the plaque. Intracameral streptokinase 1000 IU under mask anaesthesia caused complete dissolution of the fibrin leaving a clear anterior IOL surface (Fig. 7).

\section{DISCUSSION}

Children are at greater risk of developing inflammatory reactions following lensectomy with IOL implantation. ${ }^{2-4}$ This may be evident on the first post-operative day. ${ }^{4}$ In two of our cases (4 and 6) fibrinous reactions developed on the third and fourth day respectively. Traumatic cataracts predominated in this series (6 of 8$)$. It is possible that trauma associated with the presence of blood or cortical material in the anterior chamber will predispose to disruption of the blood-aqueous barrier, resulting in an excess of fibrin after surgery. Blood has been previously implicated in this regard. ${ }^{5}$ A greater amount of manipulation is often required in the 


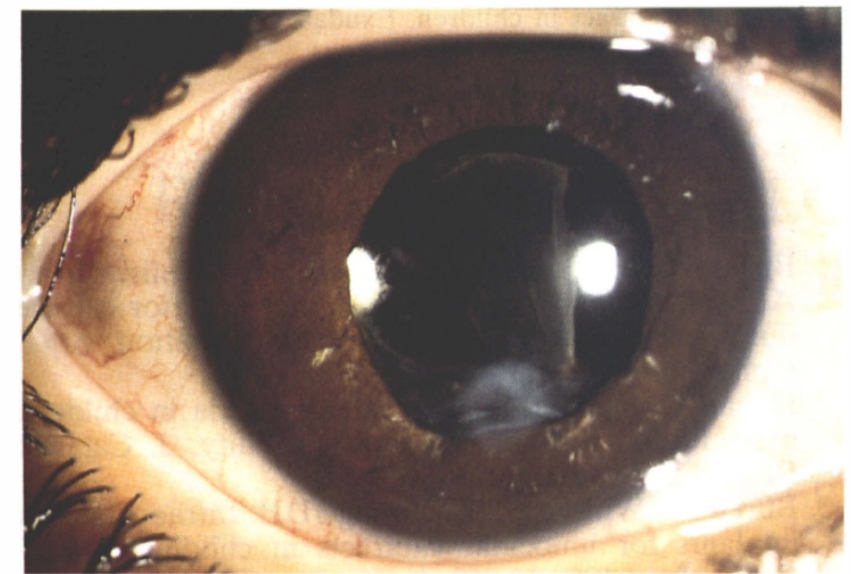

Fig. 4. Case 3. Fibrinous veil seen on the first postoperative day.

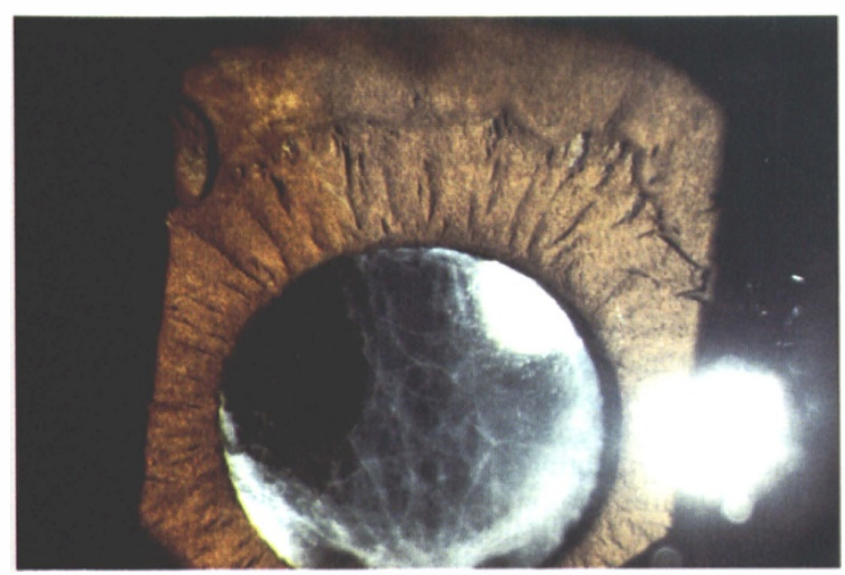

Fig. 6. Case 4. Fibrin plaque adherent to IOL.

surgical management of traumatic cataracts. Surgical trauma, particularly synechialysis, will predispose to post-operative fibrin formation. We did not administer pre-operative topical steroids. It is possible that their use might reduce post-operative fibrinous reaction.

In most patients, the post-operative anterior chamber reaction can be suppressed with intensive topical fortified steroids. Once fibrin forms, its dissolution is more difficult, though not impossible with topical treatment. If inadequate resolution occurs with the administration of fortified steroids, further intraocular surgery or the administration of fibrinolytic agents are the only therapeutic avenues available. The persistence of an axial fibrin plaque variably adherent to the IOL may compromise the surgical goal of maintaining a clear visual axis which is essential in the treatment of amblyopia. Other complications associated with fibrin membrane formation include miosis due to fixed tonic pupils and the development of pupillary block glaucoma. This

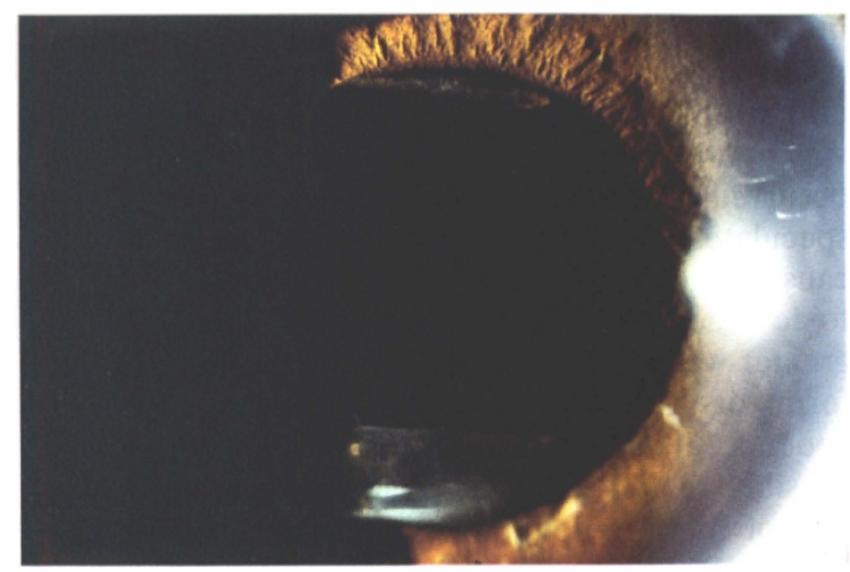

Fig. 5. Case 3. Dissolution of veil 6 hours after the administration of streptokinase.

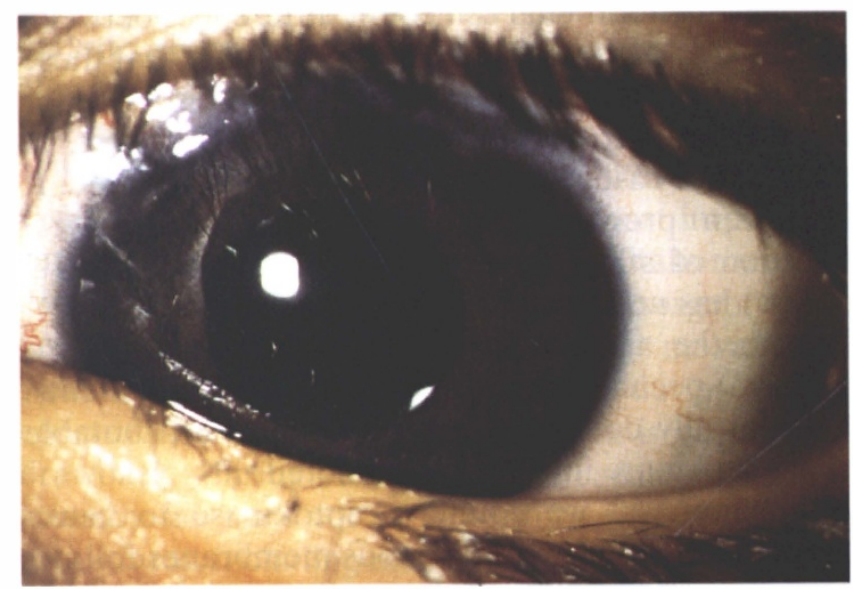

Fig. 7. Case 4. Dissolution of plaque following intracameral streptokinase.

occurred in our series, as case 6 developed pupil block glaucoma.

Tissue plasminogen activator (TPA) is a useful fibrinolytic agent in the treatment of post-cataractextraction fibrinous membranes. ${ }^{6}$ Effective lysis of fibrinous membranes which form after diabetic vitrectomy surgery and penetrating keratoplasty has been reported with TPA. ${ }^{7-9}$ The main drawback to its use is high cost. ${ }^{10}$ Intracameral streptokinase is also effective in fibrinolysis and is considerably cheaper. ${ }^{11}$ Streptokinase is a non-enzymatic protein produced by Group $C \beta$-haemolytic streptococci that acts to convert plasminogen to plasmin which then enzymatically degrades fibrin. We found that streptokinase effectively lysed fibrin membranes within 24 hours of administration in 7 of 8 eyes. In case 1 lysis was slower but complete dissolution eventually occurred.

Toxic effects on the corneal endothelium of rabbits were noted previously with intracameral streptokinase when injected in doses of 15000 units or greater. ${ }^{12,13}$ Smillie $^{12}$ recorded corneal opacification 
in nine rabbit eyes with hyphaema which had received between 15000 and 30000 IU of intracameral streptokinase. In three eyes, this opacification was permanent. However, corneal opacification also occurred in three control eyes with hyphaema. $\mathrm{He}$ speculated that acute congestive glaucoma was the cause rather than streptokinase. ${ }^{12}$ O'Rourke ${ }^{13}$ noted toxic reactions when injections of 50000 units or greater were administered. These reactions took the form of transient anterior uveitis and corneal oedema. It was felt that these side effects were possibly related to trace hyaluronidase contamination of the streptokinase.$^{13}$ Cherfan et al. ${ }^{11}$ administered 1000 IU of streptokinase to nine patients with severe fibrinous reactions after pars plana vitrectomy. They found complete lysis of all membranes within 4 hours of injection with no discernible side effects. Post-operative specular microscopy showed significant endothelial cell count differences between operated and non-operated eyes. They felt that these differences could be attributed to either surgery or intracameral streptokinase injection. ${ }^{11}$ However, in none of our cases was more than 1000 IU injected. It has been previously suggested that intracameral injection of streptokinase in small doses (1000 IU or less) has no toxic effects on rabbit endothelium. ${ }^{11}$ Due to the age limitations, it was not possible to perform specular microscopy on any of our patients. No clinically detectable adverse effects attributable to streptokinase injection were noted.

In summary, we found streptokinase to cause complete dissolution of fibrinous membranes following cataract surgery in children, thus sparing our patients further surgical intervention. We advocate that consideration be given to this relatively safe and efficacious treatment when this vision-threatening complication follows paediatric cataract surgery. We emphasise, though, that intracameral streptokinase should only be used in significant fibrinous uveitis which is refractory to standard modalities of treatment.
Key words: Cataract in children, Exudate, Fibrin, Lensectomy, Streptokinase.

\section{REFERENCES}

1. Buckley EG, Klombers LA, Seaber JH, Scalise-Gordy A, Minzter R. Management of the posterior capsule during pediatric intraocular lens implantation. Am J Ophthalmol 1993;115:722-8.

2. Dahan E, Salmenson BD. Pseudophakia in children: precautions, techniques, and feasibility. J Cataract Refract Surg 1990;16:75-82.

3. Burke JP, Willshaw HE, Young JDH. Intraocular lens implants for uniocular cataracts in childhood. $\mathrm{Br} \mathrm{J}$ Ophthalmol 1989;73:860-4.

4. Gimbel HV, Ferensowicz M, Raanan M, DeLuca M. Implantation in children. J Pediatr Ophthalmol Strabismus 1993;30:69-79.

5. Baltatzis S, Georgopoulos G, Theodossiadis P. Fibrin reaction after extracapsular cataract extraction: a statistical evaluation. Eur J Ophthalmol 1993;3:95-7.

6. Moon J, Chung S, Myong Y, Chung S, Park C, Baek N, Rhee S. Treatment of postcataract fibrinous membranes with tissue plasminogen activator. Ophthalmology 1992;99:1256-9.

7. Dabbs CK, Aaberg TM, Aguilar HE, Sternberg P Jr, Meredith TA, Ward AR. Complications of tissue plasminogen activator therapy after vitrectomy for diabetes. Am J Ophthalmol 1990;110:354-60.

8. Heidemann DG, Williams GA, Blumenkranz MS. Tissue plasminogen activator and penetrating keratoplasty. Ophthalmic Surg 1990;21:364-5.

9. Jaffe GJ, Abrams GW, Williams GA, Han DP. Tissue plasminogen activator for postvitrectomy fibrin formation. Ophthalmology 1990;97:184-9.

10. Williams GA. Discussion of paper [Cherfan GM, ElMaghraby A, Tabbara KF, Nasr Y, Hassan $\mathrm{H}$. Dissolution of intraocular fibrinous exudate by streptokinase]. Ophthalmology 1991;98:874.

11. Cherfan GM, El-Maghraby A, Tabbara KF, Nasr Y, Hassan H. Dissolution of intraocular fibrinous exudate by streptokinase. Ophthalmology 1991;98:870-4.

12. Smillie JW. The effect of streptokinase on simulated hyphema: with a study of its toxicity to anterior chambers of rabbits. Am J Ophthalmol 1954;37:911-7.

13. O'Rourke JF. An evaluation of intraocular streptokinase. Am J Ophthalmol 1955;39:119-36. 